\title{
Screening of blood donors for IgA deficiency: a study of the donor population of south-west England
}

\author{
P. D. J. HOLT, N. P. TANDY, AND D. J. ANSTEE \\ From the South West Regional Blood Transfusion Centre, Southmead Road, Bristol BS10 5ND, UK
}

SUMMARY Altogether 29745 English blood donors were screened for IgA deficiency by double diffusion analysis; 57 had apparent absence of $\operatorname{IgA}$, a frequency of 1:522. Further examination by the more sensitive haemagglutination inhibition assay revealed 34 samples having no detectable IgA, a frequency of 1:875. All donors negative by double diffusion analysis were tested for the presence of antibodies to IgA. Six class specific anti IgA antibodies and four anti IgA antibodies of limited specificity were detected. Three of these had the specificity anti $\alpha 2$ and one anti A2m(2). The $34 \operatorname{IgA}$ deficient donors detected provide a source of $\operatorname{IgA}$ deficient blood for transfusion to patients with anti IgA antibodies.

Selective IgA deficiency is the most common immunoglobulin deficiency. It has been shown to be associated with numerous disorders including ataxia telangiectasia, recurrent respiratory tract infection, coeliac disease, and many autoimmune diseases (Hobbs, 1968; Ammann and Hong, 1971 ; Bergström et al., 1973). Selective IgA deficiency has also been found in apparently healthy blood donors with a frequency ranging from 1:300 to 1:3000 (Johansson et al., 1968; Natvig et al., 1971; Frommel et al., 1973; Koistinen, 1975; Vyas et al., 1975).

The relatively high frequency of this major immunoglobulin deficiency in turn gives rise to problems in transfusion practice. Individuals with IgA deficiency may have antibodies to IgA (Vyas and Fudenberg, 1971). These antibodies, usually known as 'class specific' anti IgA antibodies because they react with all IgA proteins tested, can be the cause of serious anaphylactic transfusion reactions (Vyas et al., 1968b; Schmidt et al., 1969; Bjerrum and Jersild, 1971; Leikola et al., 1973; Pineda and Taswell, 1975). In addition, some patients with apparently normal levels of IgA can produce antibodies of limited specificity, reacting with some but not all IgA proteins. These antibodies may also cause transfusion reactions (Vyas et al., 1968b; Pineda and Taswell, 1975).

In cases of transfusion reaction due to anti IgA antibodies it is important to provide compatible blood or plasma derived from IgA deficient donors. The aim of this study was to establish a panel of IgA deficient blood donors to meet this need.

Received for publication 28 April 1977.

\section{Material and methods}

SCREENING FOR IgA DEFICIENCY

Serum samples from 29745 volunteer blood donors were tested by double diffusion analysis in a medium containing $1 \%$ agarose (BDH, Poole, UK), in phosphate buffered saline (PBS) pH 7.3 (Dulbecco 'A', Oxoid, Basingstoke, UK) using a monospecific anti-IgA serum. The anti-IgA serum was prepared by immunising rabbits with a pool of four purified monoclonal IgA proteins. The antiserum was rendered specific for IgA by absorption with a pool of purified monoclonal IgG and IgM proteins. The lowest level of IgA detected in this double diffusion system was defined as $\mathbf{4 0} \mu \mathrm{g} \mathrm{IgA} / \mathrm{ml}$ serum using a standard serum (Hoechst Pharmaceuticals, Hounslow, UK). Those sera failing to give a line of precipitation in the double diffusion screening test were further examined in a haemagglutination inhibition system using five haemagglutinating doses of a human class specific anti-IgA serum (JM) and human group $\mathrm{O}$ red cells coated with $\mathrm{IgAl}$ protein (Vyas and Fudenberg, 1971). The lowest level of IgA detected in the haemagglutination inhibition system was 0.5 $\mu \mathrm{g} \mathrm{IgA} / \mathrm{ml}$ serum. Only sera which failed to show any inhibition of the agglutinator were classified as IgA deficient (that is, less than $0.5 \mu \mathrm{g} \mathrm{IgA/ml}$ ).

DETECTION OF ANTIBODIES TO IgA, IgM, AND I gG

Antibodies to IgA were detected by passive haemagglutination assay using a panel of six IgA myeloma proteins (Table 1) by the chromic chloride method of Gold and Fudenberg (1967). Optimal conditions for 
Table 1 Protein coats used in passive haemagglutination tests

\begin{tabular}{llll}
\hline Proteins' & Immunoglobulin class & 'H' chain allotype & ' $L$ ' chain type \\
\hline Hanks & IgA & - & Lambda \\
Watts & IgA & - & Kappa \\
Yeates & IgA & - & Kappa \\
Herbert & IgA & A2m (1) & Kappa \\
Bruton & IgA & A2m (2) & Lambda \\
Schnell & IgA & - & Kappa \\
Bennett & IgM & - & Kappa \\
Box & IgM & - & Kappa \\
Crumpler & IgM & - & Lambda \\
Turl & IgM & Glm $(1,2,17)$ & - \\
& IgG & Glm $(1,2)$ & - \\
Anti-D GD-782 & IgG & Glm $(1,17)$ & - \\
Anti-D GD-59 & IgG & Glm (3) & - \\
Anti-D GD-97 & IgG & G3m $(5,10,11,13,14)$ & - \\
Anti-D GD-99 & IgG & G3m $(5,10,11,14)$ & - \\
Anti-D GD-110 & IgG & Km $(1,2)$ & Kappa \\
Anti-D GD-68 & IgG Kappa & & \\
Anti-D GD-93 & & & \\
\hline
\end{tabular}

${ }^{1}$ IgA proteins purified by method of Fine and Steinbuch (1970); IgM proteins purified by method of Johnson (1970).

${ }^{2} \mathrm{Gm}$ and $\mathrm{Km}$ coating sera supplied by Miss D. M. Brazier, Blood Group Reference Laboratory, Gatliffe Road, London, UK.

Table 2 Results of testing volunteer blood donors for the absence of $\operatorname{Ig} A$ by double diffusion and haemagglutination inhibition assays

\begin{tabular}{lrl}
\hline & $\begin{array}{l}\text { No. of } \\
\text { samples }\end{array}$ & Frequency \\
\hline Total samples tested & 29745 & - \\
IgA deficient by double diffusion & 57 & $1: 522$ \\
$(<40 \mu \mathrm{g}$ IgA $/ \mathrm{ml})$ & 34 & $1: 875$ \\
IgA deficient by haemagglutination inhibition & & \\
$\begin{array}{l}\text { (<0.5 } \mu \mathrm{g} \text { IgA/ml) } \\
\text { Very low level IgA } \\
(0.5-40 \mu \mathrm{g} I \mathrm{IA} / \mathrm{ml})\end{array}$ & 23 & $1: 1293$ \\
\hline
\end{tabular}

the coupling of the proteins were determined by the chequerboard method. The IgA coated cells were used at a concentration of $1 \%$ in PBS containing 2.5 $\mathrm{mg} / 100 \mathrm{ml}$ poly-vinylpyrolidone (PBS-PVP buffer) in V-shaped microtitre plates by the method of Vyas et al. (1968a). Sera were screened for antibodies at initial dilutions of $1 / 4$ and $1 / 8$ in PBS-PVP buffer. Antibodies detected in the screening tests were titrated and confirmed by specific inhibition tests using purified paraproteins as described by Vyas and Fudenberg (1971). Antibodies to IgM were detected by similar methods using a panel of four purified IgM paraproteins. Antibodies to IgG (Gm antibodies) were detected by incubating test serum at a dilution of $1 / 4$ in saline with $2 \%$ saline suspensions of group $\mathrm{O} \mathrm{CD} \overline{\mathrm{e}} / \mathrm{cDE}$ cells coated with incomplete anti-D (selected for their ability to coat certain $\mathrm{Gm}$ and $\mathrm{Km}$ antigens) for two hours at $20^{\circ} \mathrm{C}$ (Table 1).

\section{Results}

Of 29745 serum samples from volunteer blood donors tested by the double diffusion precipitation method, 57 were found to have less than $40 \mu \mathrm{g} \mathrm{IgA/}$ $\mathrm{ml}$ serum (a frequency of 1:522). The 57 samples were further examined for the presence of $\operatorname{IgA}$ by the more sensitive haemagglutination inhibition method 23 samples contained detectable IgA by this method The remaining 34 samples had less than $0.5 \mu \mathrm{g} \operatorname{IgA}$ $\mathrm{ml}$ serum and were denoted IgA deficient for the purposes of this study (Table 2).

The $34 \operatorname{IgA}$ deficient sera $(<0.5 \mu \mathrm{g} \operatorname{IgA} / \mathrm{ml})$ and those sera with very low level $\operatorname{IgA}(0 \cdot 5-40 \mu \mathrm{g} \mathrm{IgA} / \mathrm{ml})$ were examined for the presence of antibodies to IgA, IgM, and IgG by the passive haemagglutination method (see Methods) and the results are presented in Table 3. Antibodies specific for IgA but reacting with all six IgA coats (class specific) were found in six serum samples. Three samples contained antibodies specific for the IgA2 subclass of IgA (anti $\alpha 2$ antibodies) and one serum contained an antibody specific for the allotype A2m(2). Four samples contained anti IgM of limited specificity reacting with some but not all IgM coats. One sample contained an anti-Gm antibody specific for the $\mathrm{Glm}(1)$ allotype. In no case were anti IgA antibodies found in the 23 sera having very low levels of $\operatorname{IgA}(0.5-40$ $\mu \mathrm{g} / \mathrm{ml})$.

\section{Discussion}

The frequency of IgA deficiency has been the subject of study by a number of workers (Bachmann, 1968; Frommel et al., 1973; Hobbs, 1968; Johansson et al., 1968; Natvig et al., 1971; Koistinen, 1975; Vyas et al., 1975) and reported values vary from $1: 300$ to $1: 3000$. This variation, although reflecting differences 
Table 3 Antibodies found in serum samples containing less than $40 \mu \mathrm{g} I \mathrm{~A} / \mathrm{ml}$

\begin{tabular}{llllllc}
\hline & $\begin{array}{l}\text { No. } \\
\text { tested }\end{array}$ & $\begin{array}{l}\text { Class specific } \\
\text { anti IgA low } \\
\text { titre }(<256)\end{array}$ & $\begin{array}{l}\text { Class specific } \\
\text { anti IgA high } \\
\text { titre }(>256)\end{array}$ & $\begin{array}{l}\text { Anti IgA } \\
\text { of limited } \\
\text { specificity }\end{array}$ & $\begin{array}{l}\text { Anti IgM } \\
\text { of limited } \\
\text { specificity }\end{array}$ & $\begin{array}{l}\text { Anti Gm/Km } \\
\text { antibodies }\end{array}$ \\
\hline $\begin{array}{l}\text { IgA deficient } \\
(<0.5 \mu \mathrm{g} \text { IgA } / \mathrm{ml})\end{array}$ & 34 & 2 & 4 & 4 & 3 & 1 \\
$\begin{array}{l}\text { Very low level IgA } \\
(0.5-40 \mu \mathrm{g} \text { IgA } / \mathrm{ml})\end{array}$ & 23 & 0 & 0 & 0 & 1 & 0 \\
\hline
\end{tabular}

in the populations studied, is to some extent due to the different techniques employed to define IgA deficiency (immunodiffusion, passive haemagglutination, radioimmunoassay). The results presented here for blood donors in England (frequency 1:875 using passive haemagglutination inhibition) are in broad agreement with data obtained by other workers using the same methods; in America, Vyas et al. (1975) found a frequency of 1:886 from a series of 73569 blood donors, and in Finland Koistinen (1975) found 1:507 from 64588 donors. The more sensitive method of radioimmunoassay has not been employed in this study, but from the data of Koistinen (1975) it would be expected that some of the donors defined as $\operatorname{IgA}$ deficient in this report would be found to have very low levels of IgA by this method.

The presence of specific anti IgA antibodies in the serum of IgA deficient blood donors is well known. In this study six of $34(18 \%)$ IgA deficient donors were found to have class specific anti $\operatorname{IgA}$ antibodies, a finding in broad agreement with that of other workers (Koistinen and Sarna, 1975; Vyas et al., 1975). In disease states associated with IgA deficiency the frequency of such antibodies is much higher, that is, 40-44\% (Cassidy et al., 1969; Vyas et al., 1969; Ammann and Hong, 1971; Nadorp et al., 1973), and this may be related to the higher incidence of blood transfusion in such patients.

An interesting finding of this study has been the presence of anti IgA antibodies of limited specificity in four of the $34 \mathrm{IgA}$ deficient donors. The presence of antibodies of limited specificity in IgA deficient individuals has not been widely reported (van Loghem et al., 1973; Nadorp et al., 1973).

Human antibodies to IgM are known to occur in normal donor populations (Leikola et al., 1971; Wells et al., 1973); as yet no clinical problems have been related to their presence and their significance remains unclear. The antibodies found in this study are of low titre (1/4-1/16) and so are unlikely to cause problems in transfusion.

The $34 \operatorname{IgA}$ deficient donors detected form the basis of a panel of $\operatorname{IgA}$ deficient donors providing blood for transfusion to patients with anti IgA antibodies. Similar donor panels are also available in
America, Canda, Denmark, and Finland (Vyas and Perkins, 1976).

We are indebted to Dr E. van Loghem, Amsterdam, for subtyping our IgA proteins and for confirming the specificity of antibodies detected; to Drs Koistinen and Leikola, Helsinki, for the gift of human anti $\operatorname{IgA}$ serum (JM) and $\operatorname{IgA}$ proteins; and to Dr Skvaril, Zürich, for the gift of plasma (Schnell) containing the IgA2 (A2m2) protein. We also thank Dr J. Bothamley, RTC Bristol for making available large quantities of plasma from patients with monoclonal proteins undergoing plasmapheresis. The technical help of many colleagues from RTC Bristol is gratefully acknowledged.

\section{References}

Ammann, A. J., and Hong, R. (1971). Selective IgA deficiency: presentation of 30 cases and a review of the literature. Medicine, 50, 223-236.

Bachmann, R. (1968). Studies on the serum $\gamma$ A-globulin level. III. The frequency of A- $\gamma-\mathbf{A}$ globulinemia. Scandinavian Journal of Clinical and Laboratory Investigation, 17, 316-320.

Bergström, K., Britton, M., Hanson, L. A., Holm, G., Kardos, M., and Wester, P. O. (1973). IgA deficiency and autoimmune haemolytic anaemia. Scandinavian Journal of Haematology, 11, 87-91.

Bjerrum, O. J., and Jersild, C. (1971). Class-specific antiIgA associated with severe anaphylactic transfusion reactions in a patient with pernicious anaemia. Vox Sanguinis, 21, 411-424.

Cassidy, J. T., Petty, R., Burt, A., and Sullivan, D. (1969). Anti-IgA antibodies in patients with selective $\operatorname{IgA}$ deficiency and connective tissue diseases (abstract). Clinical Research, 17, 351.

Fine, J. M., and Steinbuch, M. (1970). A simple technique for the isolation of monoclonal IgG and IgA. Revue Européenne d'Études Cliniques et Biologiques, 15, 1115 1121.

Frommel, D., Moullec, J., Lambin, P., and Fine, J. M. (1973). Selective serum IgA deficiency. Frequency among 15,200 French blood donors. Vox Sanguinis, 25, 513-518.

Gold, E. R., and Fudenberg, H. H. (1967). Chromic chloride: a coupling reagent for passive hemagglutination reactions. Journal of Immunology, 99, 859866. 
Hobbs, J. R. (1968). Immune imbalance in dysgammaglobulinaemia type IV. Lancet, 1, 110-114.

Johansson, S. G. O., Högman, C. F., and Killander, J. (1968). Quantitative immunoglobulin determination. Comparison of two methods. Estimation of normal levels and levels in persons lacking IgA and IgD. Acta Pathologica et Microbiologica Scandinavica, 74, 519530.

Johnson, I. (1970). Oligosaccharide units of human IgM. PhD Thesis, University of Bristol.

Koistinen, J. (1975). Selective IgA deficiency in blood donors. Vox Sanguinis, 29, 192-202.

Koistinen, J., and Sarna, S. (1975). Immunological abnormalities in the sera of $\operatorname{IgA}$ deficient blood donors. Vox Sanguinis, 29, 203-213.

Leikola, J., Fudenberg, H. H., Vyas, G. N., and Perkins, H. A. (1971). Isoantibodies to human IgM: serologic and immunochemical investigations. Journal of Immunology, 106, 1147-1153.

Leikola, J., Koistinen, J., Lehtinen, M., and Virolainen, M. (1973). IgA-induced anaphylactic transfusion reactions: a report of four cases. Blood, 42, 111-119.

van Loghem, E., Wang, A. C., and Shuster, J. (1973). A new genetic marker of human immunoglobulins determined by an allele at the $\alpha 2$ locus. Vox Sanguinis, 24, 481-488.

Nadorp, J. H. S., Voss, M., Buys, W. C., van Munster, P. J. J., van Tongeren, J. H. M., Aalberse, R. C., and van Loghem, Erna. (1973). The significance of the presence of anti-IgA antibodies in individuals with an IgA deficiency. European Journal of Clinical Investigation, 3, 317-323.

Natvig, J. B., Harboe, M., Fausa, O., and Tveit, A. (1971). Family studies in individuals with selective absence of $\gamma$ A-globulin. Clinical and Experimental Immunology, 8, 229-236.
Pineda, A. A., and Taswell, H. F. (1975). Transfusion reactions associated with anti-IgA antibodies. Report of four cases and review of the literature. Transfusion (Philadelphia), 15, 10-15.

Schmidt, A. P., Taswell, H. F., and Gleich, G. J. (1969). Anaphylactic transfusion reactions associated with anti-IgA antibody. New England Journal of Medicine, 280, 188-193.

Vyas, G. N., and Fudenberg, H. H. (1971). Immunobiology of human anti-IgA: a serologic and immunogenetic study of immunization to IgA in transfusion and pregnancy. Clinical Genetics, 1, 45-64.

Vyas, G. N., Fudenberg, H. H., Pretty, H. M., and Gold, E. R. (1968a). A new rapid method for genetic typing of human immunoglobulins. Journal of Immunology, 100, 274-279.

Vyas, G. N., Holmdahl, L., Perkins, H. A., and Fudenberg, H. H. (1969). Serologic specificity of human anti-IgA and its significance in transfusion. Blood, 34, 573-581.

Vyas, G. N., and Perkins, H. A. (1976). Anti-IgA in blood donors (Letter). Transfusion (Philadelphia), 16, 289-290.

Vyas, G. N., Perkins, H. A., and Fudenberg, H. H. (1968b). Anaphylactoid transfusion reactions associated with anti-IgA. Lancet, 2, 312-315.

Vyas, G. N., Perkins, H. A., Yang, Y-M., and Basantani, G. K. (1975). Healthy blood donors with selective absence of immunoglobulin A: prevention of anaphylac tic transfusion reactions caused by antibodies to IgA Journal of Laboratory and Clinical Medicine, 85, 838 842.

Wells, J. V., Bleumers, J. F., and Fudenberg, H. H. (1973). Human anti-IgM iso-antibodies: detection of IgM allotypic markers. Proceedings of the National Academy of Science (Washington), 70, 827-829. 